\title{
Enhancement of Gaseous BTEX Adsorption on RH-MCM-41 by Chlorosilanes
}

(Peningkatan Penjerapan Gas BTEX pada RH-MCM-41 oleh Klorosilana)

\author{
T. AREEROB, S. CHIARAKORN* \& N. GRISDANURAK
}

\begin{abstract}
In this research, the surface hydrophobicity of a mesoporous molecular sieve synthesized from rice husk silica, called RH-MCM41 was improved via silylation techniqueto enhance the adsorption efficiency of non-polar volatile organic compound. The effect of chlorosilane leaving on was analyzed with three silanes containing different numbers of chloride leaving group; trimethylchlorosilane (TMCS), dimethyldichlorosilane (DMDCS) and methyltrichlorosilane (MTCS). The unmodified RH-MCM-41 was soaked in $100 \mathrm{~mL}$ of $5 \% \mathrm{v} / \mathrm{v}$ of silane reagent at $30^{\circ} \mathrm{C}$ for $24 \mathrm{~h}$. The results showed that the silane loading on the RH-MCM-41 was in the order of increasing number of leaving groups as MTCS $>$ DMDCS $>$ TMCS. The crystallinity results studied by $X$-ray diffractometry indicated that the silylation did not affect the hexagonal pattern of RH-MCM-41. However, the porosity of the silylated RH-MCM-41 was significantly decreased after silylation, especially by MTCS, due to pore blocking. After silylation, the adsorption performance of gaseous BTEX (benzene, toluene, ethylbenzene and xylene) on the silylated $\mathrm{RH}-\mathrm{MCM}-41$ was determined by gas chromatography equipped with flame ionization detector (GC-FID). From the results of humidity effect on adsorbability, the BTEX adsorption capacity of the unsilylated RH-MCM-41 was dropped a half, conversely the BTEX adsorption capacity of all silylated RH-MCM-41 was decreased in range of 20$30 \%$ when the relative humidity increased from 25 to $99 \%$. This was indicated that the influence of humidity on the BTEX adsorption was relieved after silylation. In additions, the maximum BTEX adsorption capacity belonged to RH-MCM-4I silylated by TMCS which was recommended for the enhancement of non-polar volatile organic compounds adsorption.
\end{abstract}

Keywords: Adsorption; BTEX; MCM-41; rice husk silica; silylation

ABSTRAK

Dalam kajian ini, permukaan kehidrofobian penapis molekul mesoporous disintesis daripada sekam padi silika, dikenali sebagai RH-MCM41 bertambah baik melalui teknik sililasi untuk mempertingkatkan kecekapan penjerapan sebatian organik yang tidak berkutub. Kesan klorosilana yang tertinggal dianalisis dengan tiga silana yang mengandungi jumlah klorida berbeza meninggalkan kumpulan; trimetilklorosilana (TMCS), dimetildiklorisilana (DMDCS) dan metiltriklrosilana (MTCS). RH-MCM-41 yang tidak diubah suai, direndam dalam $100 \mathrm{~mL} \mathrm{5 \%} \mathrm{v/v} \mathrm{bagi} \mathrm{bahana} \mathrm{uji} \mathrm{silana} \mathrm{pada} 30^{\circ} \mathrm{C}$ untuk $24 \mathrm{~h}$. Hasil kajian menunjukkan bahawa bebanan silana ke atas RH-MCM-41 adalah dalam aturan penambahan bilangan meninggalkan kumpulan sebagai MTCS > DMDCS > TMCS. Keputusan habluran yang dikaji oleh belauan sinar-x menunjukkan bahawa sililasi tidak menjejaskan corak hexagon RH-MCM-41. Walau bagaimanapun, keliangan sililasi RH-MCM-41 menurun dengan sekata selepas sililasi, terutamanya MTCS, kerana menghalang liang. Selepas sililasi, prestasi penjerapan gas BTEX (benzena, toluena, etilbenzena dan xilena) pada sililasi RH-MCM-41 ditentukan melalui kromatografi gas dilengkapi dengan pengesan pengionan api (GC-FID). Hasil daripada serapan kelembapan menunjukkan kapasiti penjerapan BTEX sililasi RH-MCM-41 jatuh separuh, sebaliknya kapasiti penjerapan BTEX untuk semua sililasi RH-MCM-41 adalah menurun dalam julat 20-30\% apabila kelembapan bandingan meningkat daripada 25 kepada 99\%. Ini menunjukkan bahawa pengaruh kelembapan pada penjerapan BTEX lebih baik selepas sililasi. Sebagai tambahan, kapasiti maksimum penjerapan BTEX adalah kepunyaan RH-MCM-41 sililasi oleh TMCS yang dicadangkan untuk meningkatkan penjerapantidak berkutup organik meruap.

Kata kunci: BTEX; MCM-41; penjerapan; sekam padi silika; sililasi

\section{INTRODUCTION}

Nowadays, Mobil composite material number 41 (MCM41), order mesoporous silica, can be prepared from rice husk silica which is named as RH-MCM-41 (Grisdanurak et al. 2003). The RH-MCM-41 is categorized as a nanoporous material containing silicate framework like honey comb. Its pore diameter is ranged between 20-30 ̊ and its surface area is about 700-900 $\mathrm{m}^{2} \mathrm{~g}^{-1}$ (Chiarakorn et al. 2007). This material has been introduced to be an alternative adsorbent for the adsorption of various air pollutants, supporting material for catalytic reaction, ion exchange media and filter (Appaturiet al. 2012; Artklaet al. 2009; Beck et al. 1992; Chumeeet al. 2009; Klankawet al. 2012; Tong-On et al. 2009; Wantalaet al. 2010; Yoshitakeet al. 2002; Zhao \& Lu 1998). Nevertheless, it was reported that the hydrophilicity of MCM-41 surface caused low adsorbability 
when MCM-41 is applied for non-polar volatile organic compounds (VOCs) adsorption under high relative humidity condition (Branton et al. 1999; Idris et al. 2010; Ohashi et al. 1999). This is due to the existence of silanol groups ( $\mathrm{Si}-\mathrm{OH}$ ) caused by the hydrolysis of siloxane bond ( $\mathrm{Si}-\mathrm{O}-\mathrm{Si}$ ) on MCM-41 surface. To resolve this drawback, the surface modification via silylation has been introduced.

Generally, the silylation is a well-known technique for surface tailoring on several materials containing silanol groups such as MCM-41, MCM-48, SBA-1 and silica gels (Deschner et al. 2010; Koyano et al. 1997; Lin et al. 2008; Yokoi et al. 2004; Yuan et al. 2006; Zhao \& $\mathrm{Lu}$ 1998). The common reagents used for the silylation are organosilanes. The silylation reaction takes place by substituting hydroxyl of silanol on MCM-41 surface with hydrophobic alkylsilyl groups (R-Si). It is noticed that the degree of substitution depends on the number of silane leaving groups. We expected that the more alkylsilyl substitution, the more hydrophobicity. However, there are few studies focusing on the silylating techniques and effects of silane functional group on the improvement of hydrophobic surface. For example, Zhao and Lu (1998) modified MCM-41 by trimethylchlorosilane (TMCS) and claimed that the modified MCM-41 was a promising adsorbent for volatile organic compound removal. The study of Patel et al. (2011) also confirmed the enhancement of benzene adsorption in aqueous solution by silylated MCM-41 (Patel et al. 2011). Similar to our previous work, we studied the effect of different alkylsilyl groups on the degree of silylation of RH-MCM-41. Trimethylchlorosilane (TMCS) and phenyldimethylchlorosilane (PDMCS) were used as silane precursors and the ex-situ silylation was applied in this study. The results indicated that a small silane, like TMCS, could improve the hydrophobicity of RH-MCM-41 better than PDMS due to less steric hindrance effect (Chiarakorn et al. 2007). Ketcome et al. (2009) also followed our silylation technique and reported that toluene adsorption efficiency could be significantly improved by RH-MCM-41 modified with TMCS (Ketcome et al. 2009). According to the previous works, the molecular structure of silanes plays the important role in the degree of silylation. We believed that not only the size of alkylsilyl but also the number of leaving groups can affect the silylation reactivity as well as surface properties.

The urban area in Thailand has been seriously affected by indoor air pollutants such as benzene, toluene, ethylbenzene and Xylene (abbreviated as BTEX) which cause diseases including cancer and leukemia to human. Thus, the development of BTEX measurement is urgently required in order to reduce their adverse effects.Thus, this research aimed to study the effect of chlorosilane leaving groups on the silylation efficiency. Three chlorosilanes with different number of chloride leaving groups: Methyltrichlorosilane (MTCS), dimethyldichlorosilane (DMDCS) and trimethylchlorosilane (TMCS) were used as silane reagents. The chemical structures of the silanes were shown in Table 1. The physical and chemical properties of the silylated RH-MCM-41 such as crystallinity, hydrophobicity, porosity and alkylsilyl loading were investigated. The improvement of hydrophobicity was determined by the BTEX adsorption efficiency.

\section{MATERIALS AND METHODS}

\section{CHEMICALS AND REAGENTS}

All analytical grade reagents used in this study were sodium hydroxide $(\mathrm{NaOH} \geq 95 \%$, Merck), hydrochloric acid ( $\mathrm{HCl} 37 \%$, Merck), ethanol $\left(\mathrm{C}_{2} \mathrm{H}_{5} \mathrm{OH} 99.8 \%\right.$, Merck), cetyltrimethylammonium bromide (CTAB) $\left(\left[\mathrm{C}_{16} \mathrm{H}_{33} \mathrm{~N}\left(\mathrm{CH}_{3}\right)_{3}\right] \mathrm{Br} 96 \%\right.$, Fluka), methyltrichlorosilane (MTCS 98\%, Fluka), dimethyldichlorosilane (DMDCS 98\%, Fluka) and trimethylchlorosilane (TMCS 95\%, Fluka).

\section{SYNTHESIS OF RH-MCM-41}

In this study bio-silica was used as a silica source for RHMCM-41 synthesis. The rice husk silica was prepared by the acid extraction adapted from Yalcin and Sevinc (2001) and Boonpoke et al. (2011). Rice husk obtained from rice mill was boiled in $1 \mathrm{MHCl}$ at $80^{\circ} \mathrm{C}$ for $1 \mathrm{~h}$. Then, the pretreated rice husk was washed with deionized water and then calcined in a muffle furnace at $650^{\circ} \mathrm{C}$ for $4 \mathrm{~h}$. The extracted rice husk silica was mixed with sodium hydroxide and cetyltrimethylammonium bromide (CTAB), which was used as a cationic template, with the molar composition of $1 \mathrm{SiO}_{2}$ : $1.09 \mathrm{NaOH}: 0.13$ CTAB: $120 \mathrm{H}_{2} \mathrm{O}$. The $\mathrm{pH}$ of solution was controlled at 10 and then the solution was stirred for $48 \mathrm{~h}$ at room temperature under atmospheric condition (Chiarakorn et al. 2007; Grisdanurak et al. 2003). The white suspended solid was filtered, rinsed with ethanol and distillated water and then calcined at $550^{\circ} \mathrm{C}$ for $5 \mathrm{~h}$. After the synthesis, the physical and chemical

TABLE 1. Chemical structures and molecular weight of silane reagents

\begin{tabular}{|c|c|c|c|}
\hline Chemical name & $\begin{array}{c}\text { Trimethylchlorosilane } \\
\text { (TMCS) }\end{array}$ & $\begin{array}{c}\text { Dimethyldichlorosilane } \\
\text { (DMDCS) }\end{array}$ & $\begin{array}{c}\text { Methyltrichlorosilane } \\
\text { (MTCS) }\end{array}$ \\
\hline Molecular weight $\left(\mathrm{g} \mathrm{mol}^{-1}\right)$ & 108.64 & 129.06 & 149.48 \\
\hline Silane structure & $\begin{array}{l}\mathrm{H}_{3} \mathrm{C}_{\mathrm{J}} \\
\mathrm{H}_{3} \mathrm{C}^{\prime}\end{array}$ & $\underbrace{\mathrm{Cl}-\mathrm{Cl}_{3}}_{\mathrm{H}_{2} \mathrm{C}}$ & ${ }_{\mathrm{Cl}}^{\mathrm{H}_{3} \mathrm{C}}$ \\
\hline
\end{tabular}


characteristics of the synthesized RH-MCM-41 were studied by X-ray diffraction (XRD), Fourier transform infrared spectrophotometer (FTIR) and surface area analysis (using Brunauer-Emmett-Teller, BET model). The RH-MCM-41 was used as a controlled sample, called the unsilylated RH-MCM-41 and the silylated samples were called TMCS-M, DMDCS-M and MTCS-M.

\section{SILYLATION OF RH-MCM-41}

Three chlorosilanes; trimethylchlorosilane (TMCS), dimethyldichlorosilane (DMDCS) and methyltrichlorosilane (MTCS) were used in this study. The chemical structures of the silanes were shown in Table 1. The RH-MCM-41 was silylated by the method adapted from Chiarakorn et al. (2007) and Zhao and Lu (1998). The $1 \mathrm{~g}$ of RH-MCM-41 was degassed at $200^{\circ} \mathrm{C}$ for $2 \mathrm{~h}$ and then placed in $100 \mathrm{~mL}$ of $5 \% \mathrm{v} / \mathrm{v}$ of each silane reagent. The silylation was carried out at $30^{\circ} \mathrm{C}$ for $24 \mathrm{~h}$ in a closed glass bottle. The properties such as crystallinity, porosity and surface functional groups of the RH-MCM-41 before and after the silylation were comparatively examined.

\section{CHARACTERIZATIONS}

The characteristics of the extracted rice husk silica, the unsilylated and silylated RH-MCM-41 were studied by various techniques as follows. The crystallinity was characterized by X-ray Diffraction (XRD) spectrometer (D8 Advance with Eulerian Cradle; Bruker) with $\mathrm{CuK} \alpha$ $40 \mathrm{kV}, 40 \mathrm{~mA}$ as a radiation source with the scanning at $2 \theta$ radiation in the range from $10^{\circ}$ to $35^{\circ}$ for silica and $1^{\circ}$ to $8^{\circ}$ for RH-MCM- 41 . The mineral content of the extracted silica was analyzed by Wavelength Dispersive X-Ray Fluorescence (XRF) Spectrometer (WDXRF PW2400). The dried sample was mixed with boric acid then pressed at $30 \mathrm{Nm}^{-2}$ to make the pellets. Then, the semi-quantitative (standardless) elemental analysis was performed with $\mathrm{Rh}$ as the X-ray source and the current of $100 \mathrm{~mA}$ and $24 \mathrm{kV}$. The changes of functional groups covering on RH-MCM-41 before and after silylation were analyzed by Fourier Transform Infrared Spectrometer (FTIR) (Spectrum one, Perkin Elmer, GX). The mid-infrared radiation wavenumber was scanned in the region of 400 to 4000 $\mathrm{cm}^{-1}$. The $\mathrm{N}_{2}$ adsorption-desorption isotherm, surface area, pore diameter and pore volume of the RH-MCM-41 samples were estimated by Autosorb-1 chrantachrome, BEL model (BELSORP-miniII, Osaka, BEL Japan Inc.). The volume of $\mathrm{N}_{2}$ adsorbed over the relative pressure $\left(\mathrm{P} / \mathrm{P}_{0}\right)$ of $0.05-0.35$ was used to calculate the surface area, following the Brunaure-Emmett-Teller (BET) equation. The pore size distribution (PSD) curve was plotted by Naono's model, which was especially developed for mesoporous materials (Hakuman \& Naono 2001).

The loading of alkylsilyl groups ( $\mathrm{R}-\mathrm{Si}$ ) on the $\mathrm{RH}$ MCM-41 surface was calculated in terms of the surface grafting $(\Gamma)$ and the surface density $(\alpha)$ via Liu's method
(Liu et al. 2004). The percentage of carbon content was obtained from the ultimate analysis. The loading of surface grafting $(\Gamma)$ was calculated in the unit of millimole of alkylsilyl groups per gram of silicon dioxide (mmol $\mathrm{g}^{-1} \mathrm{SiO}_{2}$ ) and the surface density of the loaded alkylsilyl groups $(\alpha)$ in the unit of groups $\mathrm{nm}^{-2}$

\section{ADSORPTION OF BTEX GASEOUS PHASE}

The improvement of hydrophobicity of the silylated RH-MCM-41 was confirmed by the BTEX adsorption. The adsorbents were degassed at $200^{\circ} \mathrm{C}$ for $2 \mathrm{~h}$. The $10 \mathrm{mg}$ of degassed adsorbents were placed into the $16000 \mathrm{~mL}$ closed chamber containing 1000 ppm of the mixed BTEX gas for $24 \mathrm{~h}$. The effect of humidity on the adsorbability of the silylated RH-MCM-41 was carried out under various relative humidity; 25, 70 and $99 \%$. After the adsorption equilibrium, the adsorbed amount was desorbed by thermal desorption unit (UNITY $2^{\mathrm{TM}}$ thermal desorber, Marks) directly to gas chromatography-flame ionization detector (GC-FID) model GC-14B from SHIMADZU, JAPAN. The GC condition used in this experiment was as follows, column: Unisole F-200, column temperature: $130^{\circ} \mathrm{C}$, injection temperature: $100^{\circ} \mathrm{C}$ and detector temperature: $150^{\circ} \mathrm{C}$.

\section{RESULTS AND DISCUSSION}

\section{SILICA EXTRACTION FROM RICE HUSK}

The crystallinity of rice husk silica (RH-silica) extracted with $1 \mathrm{M}$ of $\mathrm{HCl}$ for $1 \mathrm{~h}$ was characterized by XRD as shown in Figure 1. The diffractogram of the extracted silica showed a broad peak at $2 \theta$ equal to 23 which exhibited as amorphous form. Some oxide compounds consisting in the extracted rice husk silica was observed by XRF as shown in Table 2 . Silicon dioxide was the major component in the rice husk silica (99.76 wt. \%). The rest are trace amounts of alkaline salts such as $\mathrm{K}_{2} \mathrm{O}, \mathrm{Al}_{2} \mathrm{O}_{3}, \mathrm{Fe}_{2} \mathrm{O}_{3}$ and $\mathrm{P}_{2} \mathrm{O}_{5}$. The quality of the RH silica was comparable with that of the commercial silica. Thus, this bio-silica can be utilized as a silica source for the synthesis of various silicon-based materials.

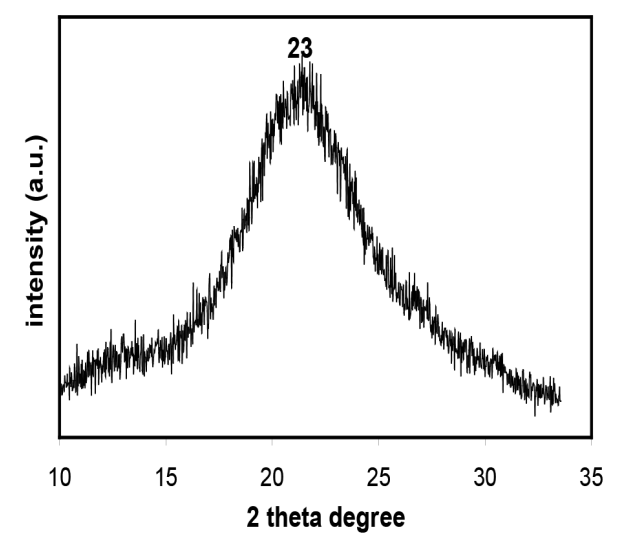

FIGURE 1. XRD diffractogram of the rice husk silica 
TABLE 2. Mineral compositions of the extracted silica from rice husk by XRF analysis

\begin{tabular}{lccccccc}
\hline Compositions & $\mathrm{SiO}_{2}$ & $\mathrm{~K}_{2} \mathrm{O}$ & $\mathrm{CaO}$ & $\mathrm{P}_{2} \mathrm{O}_{5}$ & $\mathrm{Al}_{2} \mathrm{O}_{3}$ & $\mathrm{SO}_{3}$ & $\mathrm{Fe}_{2} \mathrm{O}_{3}$ \\
\hline Rice husk silica (\%wt) & 99.76 & 0.01 & 0.01 & 0.07 & 0.10 & 0.02 & 0.03 \\
\hline
\end{tabular}

\section{THE EFFECTS OF CHLOROSILANE LEAVING GROUPS}

The Alkylsilyl Groups Loading Calculation The amount of alkylsilyl groups loading after the silylation was determined by elemental analysis. The surface grafting $(\Gamma)$ and the surface density $(\alpha)$ of the loaded functional groups on the RH-MCM-41 were calculated for all silylated samples based on carbon contents as shown in Table 3. It is observed that the surface grafting and surface density of the MTCS-M is the highest. The number of leaving groups plays more significant role in the silylating process. This result is in accordance with our hypothesis that silane containing more leaving groups might exhibit higher degree of silylation as shown in Figure 2. In addition, larger molecular size of alkylsilane (DMDCS and TMCS), one silane group reacted with only one or two $\mathrm{Si}-\mathrm{OH}$ groups due to the hindrance of larger-silane groups, resulting in less amount of degree of silylation. This result also agrees with the report of Shimojima et al. (2001), who concluded that the long-alkyl chain gave the disturbing to the degree of silane reaction with Si-OH onto silicate surface. On the other hand, the decrease of surface area and pore volume were also in agreement with the trend of alkylsilyl loading.

The Crystallinity Analysis The results from previous section indicated that some alkylsilyl groups have grafted on the surface of RH-MCM-41. Thus, the influence of grafted alkylsilyl compounds on the properties of RHMCM-41 were interesting to characterize the crystallinity transformation. The crystallinity of the unsilylated and silylated RH-MCM-41 was studied by XRD technique. Figure 3 showed the XRD diffractograms of RH-MCM-41 and RH-MCM-41 silylated with different silane reagents. All samples exhibited four diffraction peaks as the same pattern of ordered hexagonal arrays of mesoporous material, which commonly appears at $2 \theta$ equal to $2.3^{\circ}$, $4.1^{\circ}, 4.7^{\circ}$ and $6.1^{\circ}$, referred to the $h k l$ reflection planes $100,110,200$ and 210 , respectively. However, the intensity of the main peak $\left(2 \theta=2.3^{\circ}\right)$ of the silylated

TABLE 3. Porosity, alkylsilyl grafting $(\Gamma)$ and surface density $(\alpha)$ of the unsilylated and silylated RH-MCM-41

\begin{tabular}{lcccccc}
\hline Samples & $\begin{array}{c}\mathrm{S}_{\text {BET }} \\
\left(\mathrm{m}^{2} \mathrm{~g}^{-1}\right)\end{array}$ & $\begin{array}{c}\mathrm{V}_{\text {total }} \\
\left(\mathrm{cm}^{3} \mathrm{~g}^{-1}\right)\end{array}$ & $\begin{array}{c}\mathrm{Dp}_{\text {, Naono }} \\
(\AA)\end{array}$ & $\begin{array}{c}\mathrm{W} \\
(\AA)\end{array}$ & $\begin{array}{c}\Gamma \\
\left(\mathrm{mmol} \mathrm{g}^{-1} \mathrm{SiO}_{2}\right)\end{array}$ & $\begin{array}{c}\alpha \\
\left(\mathrm{groups} \mathrm{nm}^{-2}\right)\end{array}$ \\
\hline RH-MCM-41 & 797 & 0.57 & 29.0 & 16.3 & - & - \\
TMCS-M & 632 & 0.48 & 28.5 & 16.6 & 1.34 & 1.02 \\
DMDCS-M & 430 & 0.36 & 26.8 & 17.9 & 3.75 & 2.83 \\
MTCS-M & 292 & 0.28 & 28.0 & 16.8 & 6.84 & 5.17 \\
\hline
\end{tabular}

$\mathrm{S}_{\mathrm{BET}}$ : BET surface area (from $\mathrm{N}_{2}$ adsorption isotherm)

$\mathrm{V}^{\mathrm{BET}}$ : total pore volume (from $\mathrm{N}_{2}$ adsorption isotherm)

$\mathrm{D}_{\mathrm{p}}$ : mean pore diameter (from Naono's equation)

$\mathrm{W}$ : pore wall thickness $\left(\mathrm{W}=\mathrm{a}_{0}-\mathrm{Dp}\right), \mathrm{a}_{0}$ is unit cell parameter of the hexagonal pore of MCM-41

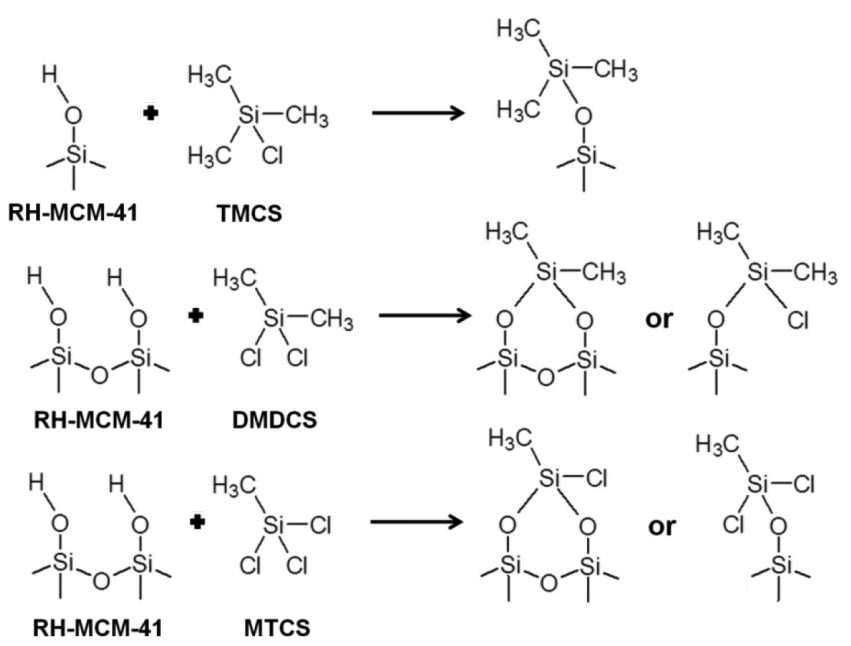

FIGURE 2. Proposed silylation mechanisms of MTCS, DMDCS and TMCS 
samples was slightly decreased. This is likely due to the organosilanes moieties filling up in the hexagonal pores, which leads to the change of surface area, pore volume and pore wall thickness (Burleigh et al. 2001; Lang \& Tuel 2004). The XRD results were evident that the hexagonal pore structure of the silylated RH-MCM-41 under condition used in this study was not affected by silane reagents. The influence of silanes was only on the surface activity, like the porosity properties of RH-MCM- 41 .

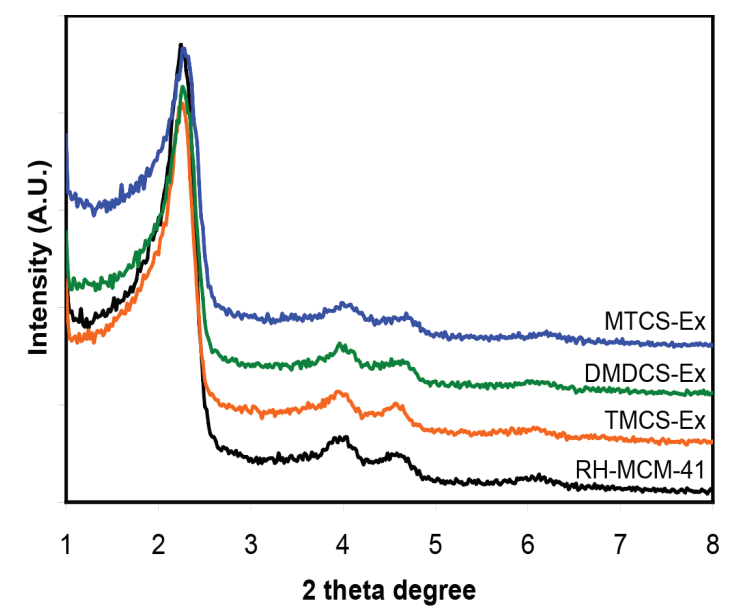

FIGURE 3. XRD diffractograms of RH-MCM-41 before and after silylation at various silane reagents:

TMCS, DMDCS and MTCS

The Porosity Analysis The $\mathrm{N}_{2}$ adsorption-desorption isotherms and pore size distribution of the unsilylated and silylated RH-MCM-41 were presented in Figures 4 and 5, respectively. The adsorption isotherm can infer to pore arrangement and interaction between adsorbent and adsorbate. According to IUPAC, the unsilylated RHMCM-41 and TMCS-M exhibited Type IV isotherm, which is the characteristic of ordered mesoporous structure. Considering at $\mathrm{p} / \mathrm{p} 0$ equal to zero, nitrogen molecules attached on the sample surface as a monolayer due to van der Waals force. In case of Type IV isotherm, the steep curve due to capillary condensation was commonly found in a range of $\mathrm{p} / \mathrm{p}_{0} \mathrm{0}-0.1$ and the stepwise of multilayer adsorption isotherms distinctly appeared at $\mathrm{p} / \mathrm{p}_{0} 0.1-0.3$. While DMDCS-M and MTCS-M gave smooth isotherms, determined as Type II, which shows low adsorbability even increasing partial pressure without stepwise of multilayer adsorptions. And there are no hysteresis loop appeared in all isotherms. This result can be explained that pore blocking might occur when the RH-MCM-41 was silylated by silanes containing many leaving groups, like DMDCS and MTCS. The more chloride leaving groups, the more surface silylating into the pore channel. The silanol groups (Si$\mathrm{OH})$ was replaced by alkylsilyl groups inside and outside the pores, resulting in the decrease of pore volume, pore diameter and surface area as seen in Table 3. This result was in agreement with Yoshitake et al. (2002).

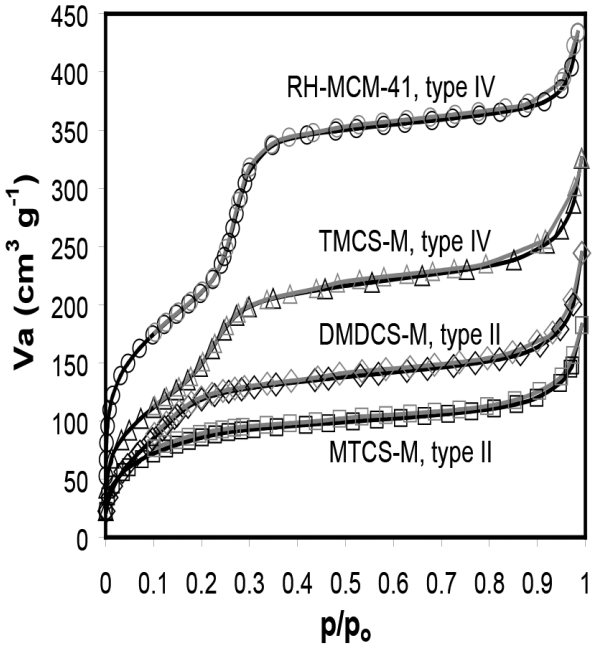

FIGURE 4. $\mathrm{N}_{2}$ adsorption-desorption isotherms of RH-MCM-41 before and after silylation at various silane reagents: TMCS, DMDCS and MTCS

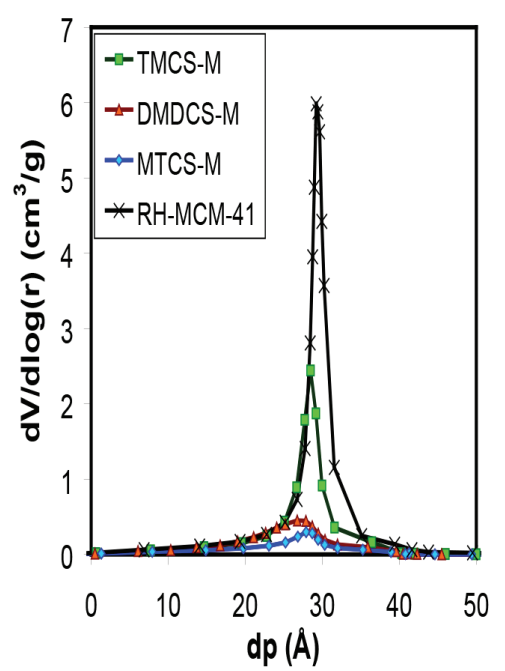

FIGURE 5. Pore size distributions of RH-MCM-41 before and after silylation with various silane reagents: TMCS, DMDCS and MTCS

The Functional Analysis The functional analysis was done to confirm the presence of alkylsilyl grafting on the RH-MCM-41. The FTIR spectrums of RH-MCM-41 before and after silylation were illustrated in Figure 6 and the positions of FTIR spectrum belonging to each silane reagents were listed in Table 4. The FTIR spectrum pattern of RH-MCM-41 showed a peak at $963 \mathrm{~cm}^{-1}$, belonged to terminal $v(\mathrm{Si}-\mathrm{OH})$, a sharp band of free $\mathrm{Si}-\mathrm{OH}$ at $3446 \mathrm{~cm}^{-1}$ and a broad peak of hydrogen-bonded $\mathrm{SiO}-\mathrm{H}$ at $3600-3500 \mathrm{~cm}^{-1}$. After silylation, the existence of silane functional groups bonding with $\mathrm{Si}-\mathrm{OH}$ on the RH-MCM-41 surface was detected. The TMCS-M had the peak of $\mathrm{Si}\left(\mathrm{CH}_{3}\right)_{3}$ at $845 \mathrm{~cm}^{-1}$ while the MTCS-M and DMDCS-M showed the asymmetric bending and stretching C-H of methyl group $\left(\mathrm{CH}_{3}\right)$ at $2960 \mathrm{~cm}^{-1}$. Moreover, it was obviously seen that the intensity of $\mathrm{Si}-\mathrm{OH}$ 
TABLE 4. Position of FTIR spectrums found in the unsilylated and ex-situ silylated RH-MCM-41 with TMCS, DMDCS and MTCS

\begin{tabular}{llc}
\hline \multicolumn{1}{c}{ Samples } & \multicolumn{1}{c}{ Functional groups } & Wavenumber $\left(\mathrm{cm}^{-1}\right)$ \\
\hline RH-MCM-41 & symmetric stretching of Si-OH & 963 \\
& broad peak of Si-OH & 3446 \\
& symmetric stretching of Si-O-Si & 801 \\
& asymmetric stretching of Si-O-Si & 1090 \\
TMCS-M & $\mathrm{Si}-\left(\mathrm{CH}_{3}\right)_{3}$, rocking & 845 \\
& $\mathrm{Si}-\left(\mathrm{CH}_{3}\right)_{3}$, sym. bending & 1255 \\
& asymmetric stretching of C-H & 2960 \\
DMDCS-M and MTCS-M & asymmetric stretching of C-H & 2953 \\
& asymmetric bending of C-H & 1452 \\
\hline
\end{tabular}

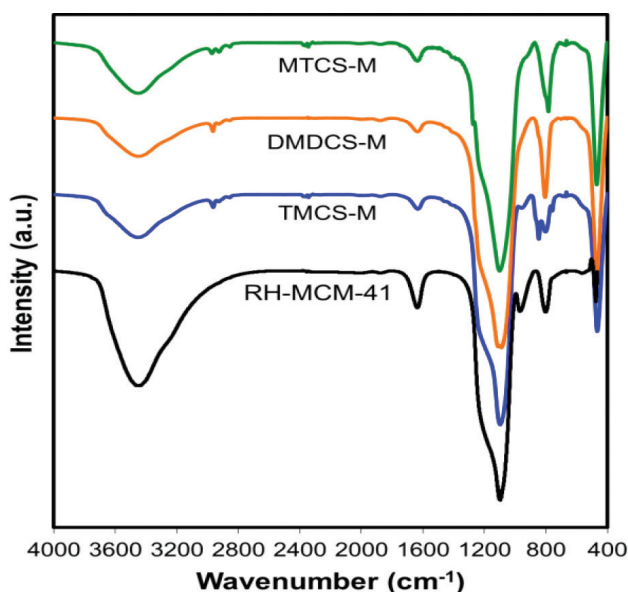

FIGURE 6. FTIR spectrum of RH-MCM-41 before and after silylation by various silane reagents:

TMCS, DMDCS and MTCS

symmetric stretching vibration at $963 \mathrm{~cm}^{-1}$ was decreased significantly because the $\mathrm{Si}-\mathrm{OH}$ groups were substituted with alkylsilyl groups (R-Si-) and the peaks at $800 \mathrm{~cm}^{-1}$ and $1082 \mathrm{~cm}^{-1}$ due to symmetric and asymmetric $v(\mathrm{Si}-\mathrm{O}-\mathrm{Si})$ were increased. This was evident that the surface silylation took place under the condition in this study.
The Effect of Humidity on BTEX Adsorption The amounts of mixed BTEX adsorbed on the unsilylated and silylated RHMCM-41 under various relative humidity; 25, 70 and 99\% were presented in Figure 7 . These results indicated that relative humidity affects the BTEX adsorption efficiency. The adsorption capacity of the unsilylated and silylated RH-MCM-41 was decreased under high relative humidity adsorption. It was obviously seen that the unsilylated sample adsorbed BTEX gas less than the others. The maximum BTEX adsorption capacity belonged to TMCS-M with the adsorbability of $123.2 \mu \mathrm{mol}$ of BTEX per $\mathrm{g}$ of TMCS-M at $25 \%$ relative humidity and $91.2 \mu \mathrm{mol}$ of BTEX per $\mathrm{g}$ of TMCS-M at $99 \%$ relative humidity.

After silylation, the BTEX adsorption efficiencies of the silylated samples were improved significantly due to the increasing of the surface hydrophobicity. Surprisingly, TMCS-M exhibited the highest BTEX adsorption capacity even though its alkylsilyl loading on the MCM-41 surface was the lowest. The BTEX adsorption capacity of TMCS-M was more than a factor of two compared with the unsilylated adsorbent. This phenomenon can be explained that more leaving groups led to better silylation reactivity but lower BTEX adsorbability due to pore blocking resulting to the decrease of pore volume and surface area. Moreover, the unreacted chlorine composed in di and trichlorosilane

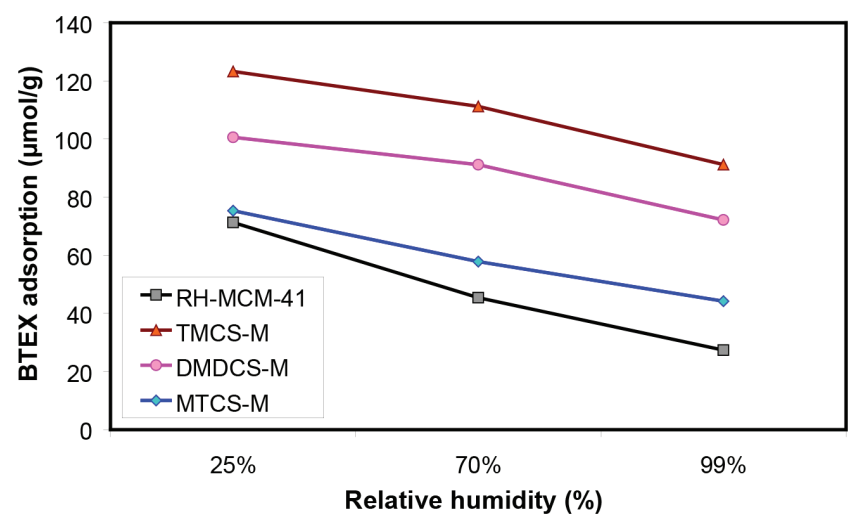

FIGURE 7. BTEX adsorption on RH-MCM-41 before and after silylation with various silane reagents at 25,70 and $99 \%$ relative humidity 
molecules might be hydrolyzed to $\mathrm{Si}-\mathrm{OH}$, increasing surface hydrophilicity (Fujita et al. 2005, 2003; Ogawa et al. 1998; Okutomo et al. 1999). Thus, it was recommended that TMCS was a promising silane for the application of silanol $(\mathrm{Si}-\mathrm{OH})$ removal. In other words, TMCS was able to improve surface hydrophobicity of RH-MCM-41. However, in case of increasing non-polar VOCs adsorbability of RHMCM-41, the effect of silylation degree and pore blocking should be taken into account. A small silane, like MTCS, was recommended for surface modification in order to avoid decrease in pore volume and surface area of the adsorbent. Humidity was another important factor affecting the BTEX adsorbability of the unsilylated and silylated RH-MCM- 41 . The severe competition between water and BTEX molecules adsorbing on RH-MCM-41 took placed under high humid condition. This was because polar-polar interaction was more preferable than non-polar and polar interaction. The strong hydrogen bonding between water molecules and hydroxyl in silanol ( $\mathrm{Si}-\mathrm{OH})$ was an obstacle for the adsorption of non-polar VOCs. When the relative humidity increased from 25 to $99 \%$, the BTEX adsorption capacity of the unsilylated RH-MCM-41 was dropped a half while the BTEX adsorption capacity of all silylated RH-MCM-41 was decreased in range of 20-30\%. This was indicated that the influence of humidity on the BTEX adsorption was relieved after silylation.
The adsorption capacity of each BTEX compounds on the unsilylated and silylated RH-MCM-41 was displayed in Figure 8. After silylation, the BTEX adsorbability of RH-MCM-41 was improved significantly, especially for ethylbenzene and $\mathrm{m}$-p xylene. The adsorption performances were in order of $\mathrm{m}, \mathrm{p}$-xylene $\approx$ ethylbenzene $>$ o-xylene $>$ toluene $>$ benzene, which are directly proportional to their molecular weights but inversely proportional to their water solubility (hydrophilicity) as shown in Table 5. The adsorption of BTEX onto modified surface of RH-MCM-41 was determined as physical adsorption, in which the van der waals force is dependent on the molecular weight of adsorbate (Liao et al. 2008). This result indicated the successful hydrophobicity enhancement on RH-MCM-41 surface.

The Adsorption Kinetic of Unsilylated RH-MCM-41 and TMCS-EX The BTEX (1000 ppm for each chemical) was prepared in $4200 \mathrm{~mL}$ of container. The time to reach equilibrium adsorption was investigated by carrying out kinetic experiments. Typically, $100 \mathrm{mg}$ of pelletized samples were taken in stainless steel net cylinder and taken in the Radiello's yellow cartridge container. The sample cylinders were collected as a function of time (every 10 min of 1 st hour and every hour since 2 nd hour) and then the amount of BTEX adsorption on adsorbents were directly

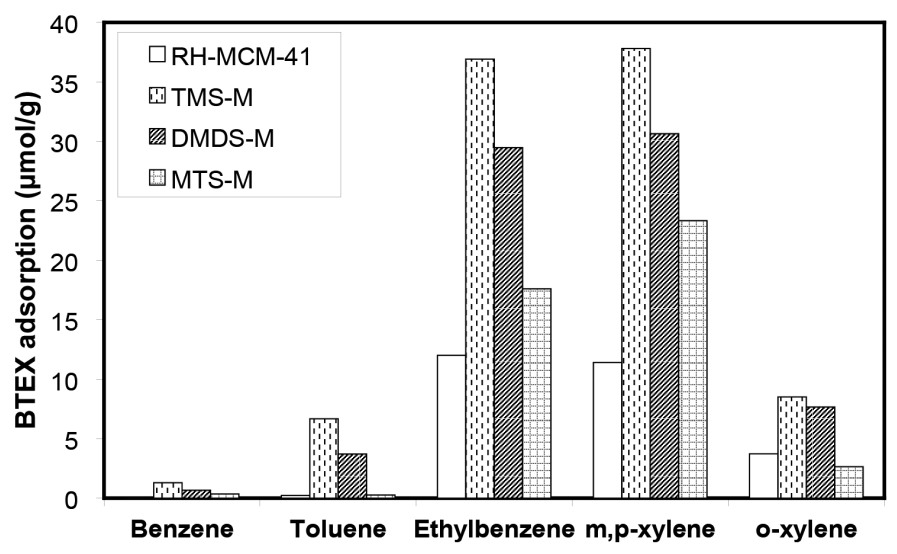

FIGURE 8 . The adsorption of BTEX on the unsilylated and silylated RH-MCM-41 at $99 \%$ relative humidity

TABLE 5. Physical properties of each BTEX (Beim et al. 1998)

\begin{tabular}{|c|c|c|c|c|}
\hline Benzene & Toluene & Ethylbenzene & Xylene & \\
\hline Molecular structure & & & & $\mathrm{CH}_{3}$ \\
\hline Molecular weight $\left(\mathrm{g} \mathrm{mol}^{1}\right)$ & 78 & 92 & 106 & 106 \\
\hline Water solubility $\left(\mathrm{mg} \mathrm{L}^{-1}\right)$ & 790.0 & 530.0 & 152.0 & 150.5 \\
\hline Boiling point $\left({ }^{\circ} \mathrm{C}\right)$ & 80.1 & 110.7 & 136.2 & 138.0 \\
\hline
\end{tabular}


estimated by GC-FID with TDU. The kinetic curves showed the amount of BTEX adsorbed on unsilylated RH-MCM-41 and TMCS-Ex in Figure 9. The initial adsorption rate is fast with the larger number of active sites availability then it is slow after $6 \mathrm{~h}$ for unsilylated RH-MCM-41 and $10 \mathrm{~h}$ for TMCS-Ex. However, $8 \mathrm{~h}$ was used as contact time to analyse the BTEX adsorption which is the work period of worker.

The kinetic parameters of BTEX adsorption onto RHMCM-41 and TMCS-Ex were given in Table 6. Considering rate constant $\left(\mathrm{k}_{1}, \mathrm{k}_{2}\right.$ and $\left.\mathrm{k}_{\text {int }}\right)$ of RH-MCM-41 and TMCS-Ex, the adsorption rate constants increased after modifying RH-MCM-41 surface via ex-situ silylation. This result is due to high adsorption feasibility between BTEX molecules and organic moiety on TMCS-Ex surface. The correlation coefficients () for the pseudo-first-order kinetic model was less than the pseudo-second-order kinetic model. It means that this adsorption process on both adsorbent was not matched by the pseudo-first-order. On the other hand, it is best fitted with pseudo-second-order kinetic model. In addition, the calculated $\mathrm{q}_{\mathrm{e}-2}$ values of TMCS-Ex is in agree with experimental $\mathrm{q}_{\mathrm{e}}$ values and also the correlation coefficients for the pseudo-second-order kinetic plots were very high.
The uptake rates of the BTEX into the adsorbents followed intraparticle diffusion model (Weber-Morris model kinetic) with time half of lives $\left(\mathrm{t}^{1 / 2}\right)$ in the range of 2-30 $\mathrm{min}^{1 / 2}$ at $30^{\circ} \mathrm{C}$ (Table 7). The TMCS-Ex show faster uptake rate than RH-MCM-41, thus indicated that the organic moieties substitution to silanol groups on RHMCM-41 play an important role on the uptake efficiency.

The diffusion of BTEX into the adsorbent can appear in several steps. After the BTEX adsorption process on external surface and surface diffusion were completely saturated, the BTEX molecule diffused into the mesoporous pore of adsorbents. After long time diffusion, the BTEX molecule resistance increased causing the decrease of diffusion rate. The initial adsorption rate of intraparticle diffusion rate $\left(\mathrm{k}_{\text {int-1 }}\right)$ was increased with the increase of BTEX adsorption efficiency of adsorbent. So, $\mathrm{k}_{\text {int- } 1}$ of TMCS-Ex exhibited slightly larger than that of unsilylated RH-MCM-41 indicating that BTEX likes to diffuse into TMCS-Ex pores more than RH-MCM-41 pores. Thus, the modification surface via silylation can improve the BTEX adsorbability.

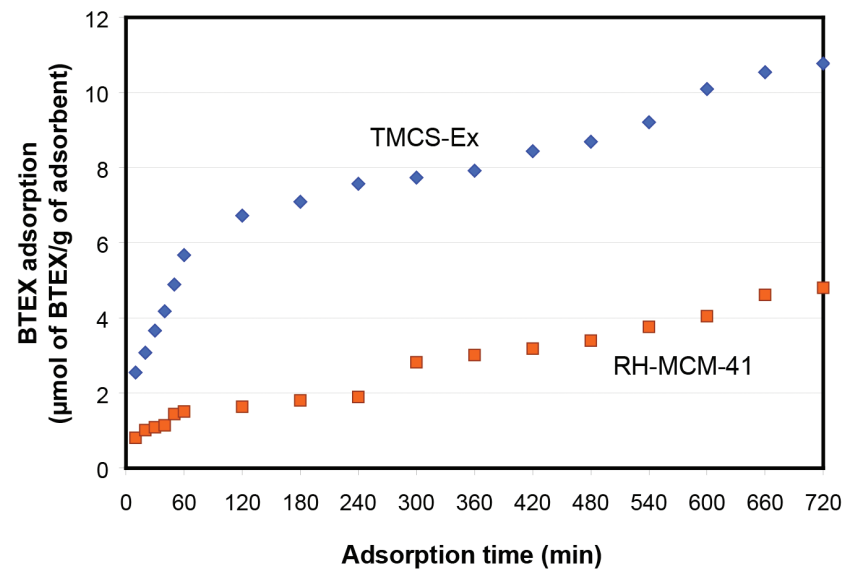

FIGURE 9. Effect of contact time for BTEX adsorbed on unsilylated RH-MCM-41and TMCS-Ex

TABLE 6. Kinetic parameters for the adsorption of BTEX onto unsilylated RH-MCM-41 and TMCS-Ex

\begin{tabular}{lcc}
\hline & RH-MCM-41 & TMCS-Ex \\
\hline $\mathrm{q}_{\mathrm{e}}$-experiment $\left(\mathrm{mmol} \mathrm{g}^{-1}\right)$ & 4.7996 & 10.7720 \\
Pseudo-first-order & & \\
$\mathrm{k}_{1}\left(\mathrm{~min}^{-1}\right)$ & 0.0032 & 0.0039 \\
$\mathrm{q}_{\mathrm{e}-1}\left(\mathrm{mmol} \mathrm{g}^{-1}\right)$ & 4.6345 & 8.0575 \\
$R_{1}^{2}$ & 0.8221 & 0.8841 \\
Pseudo-second-order & & \\
$\mathrm{k}_{2}\left(\mathrm{~g} \mathrm{mmol}^{-1} \min ^{-1}\right)$ & & \\
$\mathrm{q}_{\mathrm{e}-2}\left(\mathrm{mmol} \mathrm{g}^{-1}\right)$ & 0.0011 & 0.0015 \\
$R_{2}^{2}$ & 5.1256 & 10.6724 \\
\hline
\end{tabular}


TABLE 7. Kinetic parameters of intraparticle diffusion model for the adsorption of BTEX onto unsilylated RH-MCM-41 and TMCS-Ex

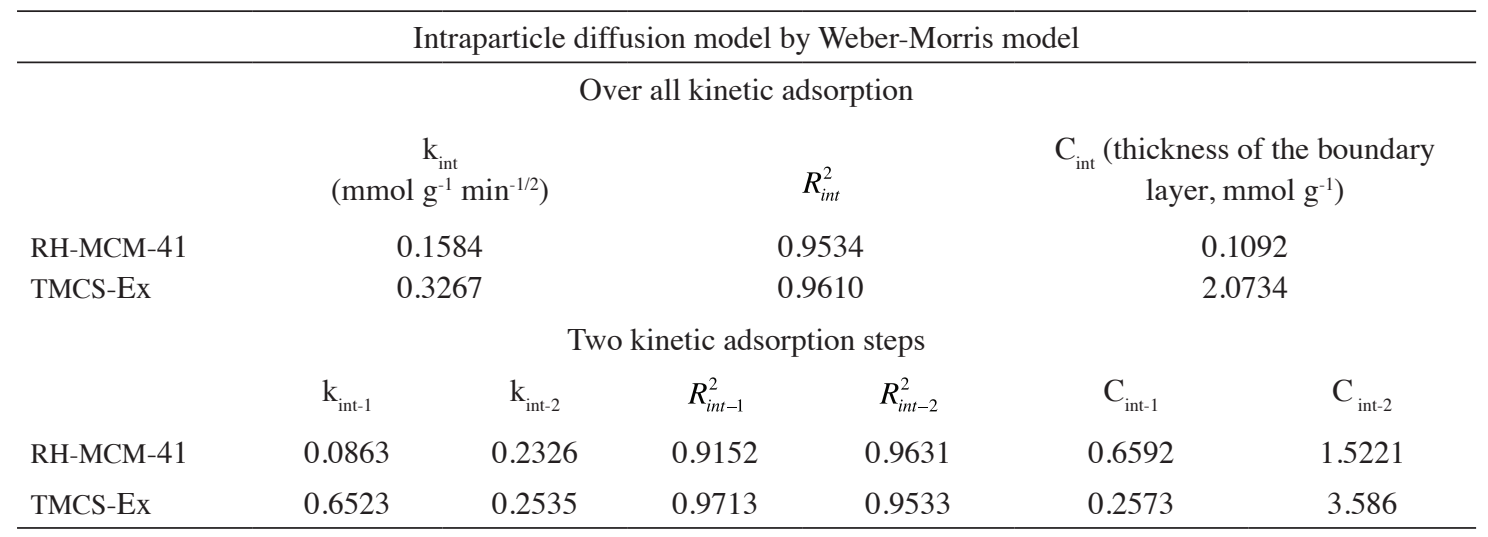

The Isotherm Adsorption Ofunsilylated RH-MCM-4I and TMCS-EX Adsorption isotherm experiments were determined in $4200 \mathrm{~mL}$ of container. Each container had the each components of BTEX in different concentration: $100,250,500,750,1000,2000,3000,4000$ and 5000 $\mathrm{ppm}$ with the contact time 8h-TwA for workday. The adsorption isotherm of BTEX were illustrated in Figure 10 as millimole of each component of BTEX adsorbed per unit weight of TMCS-Ex, plotted as a function of BTEX concentration in the vapor phase. Adsorption isotherm of BTEX onto TMCS-Ex presented the equilibrium concentration of TMCS-Ex which was nonlinear with curvatures concave to the abscissa. The amount of BTEX adsorption on TMCS-Ex increased with the increasing of BTEX concentration. For comparison, m,p-Xylene and ethylbenzene adsorption on TMCS-Ex gave the largest capacity according to the decrease in solubility and increase in molecular weight. On the other hand, the adsorption capacity gave lowest for benzene and toluene, which were directly opposite with the molecular weight.

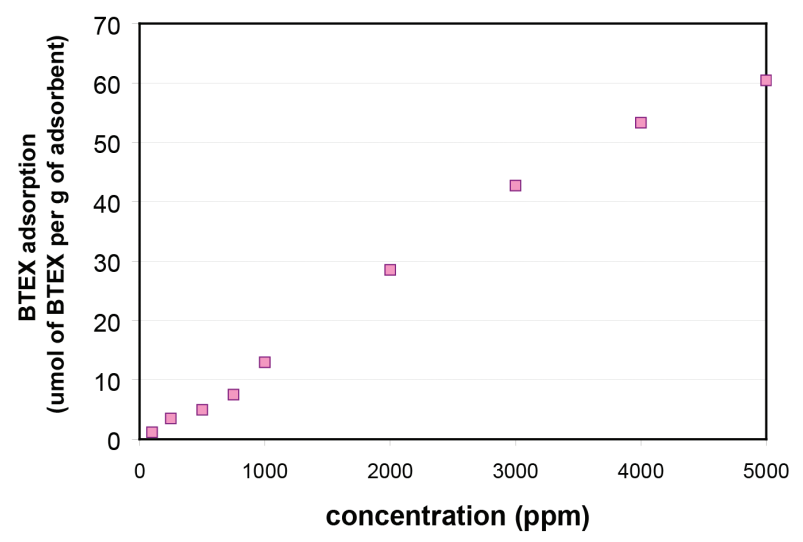

FIGURE 10. Amount of BTEX adsorbed on TMCS-Ex as a function of concentration with contact time $8 \mathrm{~h}$-TWA for workday

\section{CONCLUSION}

The BTEX adsorption capacity of RH-MCM- 41 can be improved by silylation technique. Silane leaving groups plays the important role in the degree of silylation. However, an increase in the degree of silylation leads to a decrease in the adsorbent porosity, which adversely affects the adsorption capacity for non-polar volatile organic compounds. Humidity is another parameter resulting in the reduction of BTEX adsorption capacity. To enhance the BTEX adsorbability and reduce the effect of humidity, TMCS, a small silane molecule consisted of one chloride leaving group, is a promising reagent for the surface silylation of siliceous mesoporous silica. The result from this study can be further applied for the relevant applications such as materials used as a stationary phase in gas chromatography, air sampler and catalytic support.

\section{ACKNOWLEDGEMENTS}

This work was financially supported by the Strategic Scholarship Fellows Frontier Research Networks, the office of the Higher Education Commission (THAILAND); National Nanotechnology Center (NANOTEC), National Science and Technology Development Agency, THAILAND; Division of Environmental Technology, School of Energy, Environment and Materials, King Mongkut's University of Technology Thonburi, THAILAND and the Join Graduate School of Energy and Environment (JGSEE), Center for Energy Technology and Environment, Ministry of Education Thailand.

\section{REFERENCES}

Appaturi, J.N., Adam, F. \& Khanam, Z. 2012. A comparative study of the regioselective ring opening of styrene oxide with aniline over several types of mesoporous silica materials. Microporous and Mesoporous Materials 156: 16-21.

Artkla, S., Kim, W., Choi, W. \& Wittayakun, J. 2009. Highly enhanced photocatalytic degradation of tetramethylammonium on the hybrid catalyst of titania and MCM-41 obtained from rice husk silica. Applied Catalysis B: Environmental 91(12): 157-164. 
Beck, J.S., Vartuli, C., Roth, W.J., Kresge, C.T., Schimitt, K.D., Chu, T.W., Olson, D.H., Sheppard, E.W., McCullen, S.B., Higgins, J.B. \& Schlenker, J.L. 1992. A new family of mesoporous molecular sieves prepared with liquid crystal templates. Journal of the American Chemical Society 114: 10834-10843.

Beim, H.J., Spero, J. \& Theodore, L. 1998. Rapid Guide to Hazardous Air Pollutants. New York: Van Nostrand Reinhold.

Boonpoke, A., Chiarakorn, S., Laosiripojana, N., Towprayoon, S. \& Chidthaisong, A. 2011. Synthesis of activated carbon and MCM-41 from bagasse and rice husk and their carbon dioxide adsorption capacity. Journal of Sustainable Energy and Environment 2(2): 77-81.

Branton, P.J., Reynolds, P.A., Studer, A., Sing, K.S.W. \& White, J.W. 1999. Adsorption of carbon tetrachloride by $3.4 \mathrm{~nm}$ pore diameter siliceous MCM-41: Isotherms and neutron diffraction. Adsorption 5: 91-96.

Burleigh, M.C., Markowitz, M.A., Spector, M.S. \& Gaber, B.P. 2001. Direct synthesis of periodic mesoporous organosilicas: Functional incorporation by co-condensation with organosilanes. Journal of Physical Chemistry B. 105: 9935-9942.

Chiarakorn, S., Areerob, T. \& Grisdanurak, N. 2007. Influence of functional silanes on hydrophobicity of MCM-41 synthesized from rice husk. Science and Technology of Advanced Materials 8(1-2): 110-115.

Chumee, J., Grisdanurak, N., Neramittagapong, A. \& Wittayakun, J. 2009. Characterization of platinum-iron catalysts supported on MCM-41 synthesized with rice husk silica and their performance for phenol hydroxylation. Science and Technology of Advanced Materials 10(1): Art. no. 015006.

Deschner, T., Liang, Y. \& Anwander, R. 2010. Silylation efficiency of chlorosilanes, alkoxysilanes and monosilazanes on aeriodicmesoporous silica. The Journal of Physical Chemistry C. 114: 22603-22609.

Fujita, I., Kuroda, K. \& Ogawa, M. 2005. Adsorption of alcohols from aqueous solutions into a layered silicate modified with octyltrichlorosilane. Chemistry of Materials 17: 3717-3722.

Fujita, I., Kuroda, K. \& Ogawa, M. 2003. Synthesis of interlamellarsilylatedderivatives of magadiite and the adsorption behavior for aliphatic alcohols. Chemistry of Materials 15: 3134-3141.

Grisdanurak, N., Chiarakorn, S. \& Wittayakun, J. 2003. Utilization of mesoporous molecular sieves synthesized from natural source rice husk silica to chlorinated volatile organic compounds (CVOCs) adsorption. Korean Journal of Chemical Engineering 20: 950-955.

Hakuman, M. \& Naono, H. 2001. A new method of calculating pore size distribution: Analysis of adsorption isotherms of $\mathrm{N}_{2}$ and $\mathrm{CCl}_{4}$ for a series of MCM-41 mesoporous silicas. Journal of Colloid and Interface Science 241(1): 127-141.

Idris, S.A., Robertson, C., Morris, M.A. \& Gibson, L.T. 2010. A comparative study of selected sorbents for sampling of aromatic VOCs from indoor air. Analytical Methods 2: 1803-1809.

Ketcome, N., Grisdanurak, N. \& Chiarakorn, S. 2009. Silylated rice husk MCM-41 and its binary adsorption of water-toluene mixture. Journal of Porous Materials 16: 41-46.

Klankaw, P., Chawengkijwanich, C., Grisdanurak, N. \& Chiarakorn, S. 2012. The hybrid photocatalyst of TiO2-SiO2 thin film prepared from rice husk silica. Superlattices and Microstructures 51(3): 343-352.
Koyano, K.A., Tatsumi, T., Tanaka, Y. \& Nakata, S. 1997. Stabilization of mesoporous molecular sieves by trimethylation. Journal of Physical Chemistry B. 101: 9436-9440.

Lang, N. \& Tuel, A. 2004. A fast and efficient ion-exchange procedure to remove surfactant molecules from MCM-41 materials. Chemistry of Materials 16(10): 1961-1966.

Liao, Q., Sun, J. \& Gao, L. 2008. The adsorption of resorcinol from water using multi-walled carbon nanotubes. Colloids and Surfaces A: Physicochemical and Engineering Aspects 312: 160-165.

Lin, D.H., Jiang, Y.X., Wang, Y. \& Shi-Gang, S. 2008. Silver nanoparticles confined in SBA-15 mesoporous silica and the application as a sensor for detecting hydrogen peroxide. Journal of Nanomaterials. Article ID 473791 doi:10.1155/2008/473791.

Liu, Y.H., Lin, H.P. \& Mou, C.Y. 2004. Direct method for surface silylfunctionalization of mesoporous silica. Langmuir 20(8): 3231-3239.

Ogawa, M., Okutomo, S. \& Kuroda, K. 1998. Control of interlayer microstructures of a layered silicate by surface modification with organochlorosilanes. Journal of the American Chemical Society 120: 7361-7362.

Ohashi, F., Maeda, M., Inukai, K., Suzuki, M. \& Tomura, S. 1999. Study on intelligent humidity control materials: Water vapor adsorption properties of mesostructured silica derived from amorphous fumed silica. Journal of Materials Science 34(6): 1341-1346.

Okutomo, S., Kuroda, K. \& Ogawa, M. 1999. Preparation and characterization of silylated-magadiites. Applied Clay Science 15: 253-264.

Patel, D.B., Singh, S. \& Bandyopadhyaya, R. 2011. Enrichment of benzene from benzene-water mixture by adsorption in silylated mesoporous silica. Microporous and Mesoporous Materials 137(1-3): 49-55.

Shimojima, A., Mochizuki, D. \& Kuroda, K. 2001. Synthesis of silylatedderivatives of a layered polysilicatekanemite with mono-, di-, and tri-chloro(alkyl)silanes. Chemistry of Materials 13: 3603-3609.

Tong-On, W., Sthiannopkao, S., Kim, K.W. \& Chiarakorn, S. 2009. Adsorption of arsenic in aqueous solution by RHFe-MCM-41. Water Science and Technology: Water Supply 9(2): 121-126.

Wantala, K., Sthiannopkao, S., Srinameb, B., Grisdanurak, N. \& Kim, K.W. 2010. Synthesis and characterization of FeMCM-41 from rice husk silica by hydrothermal technique for arsenate adsorption. Environmental Geochemistry and Health 32(4): 261-266.

Yalcin, N. \& Sevinc, V. 2001. Studies on silica obtained from rice husk. Ceramic International 27(2): 219-224.

Yokoi, T., Yoshitake, H.\& Tatsumi, T. 2004. Synthesis of aminofunctionalized MCM-41 via direct co-condensation and post-synthesis grafting methods using mono-, di- and triamino-organoalkoxysilanes. Journal of Materials Chemistry 14: 951-957.

Yoshitake, H., Yokoi, T. \& Tatsumi, T. 2002. Adsorption of chromate and arsenate by amino-functionalized MCM-41 and SBA-1. Chemistry of Materials 14(11): 4603-4610.

Yuan, P., Yang, D., Lin, Z.G., He, H.P., Wen, X.Y., Wang, L.J. \& Deng, F. 2006. Influences of pretreatment temperature on the surface silylation of diatomaceous amorphous silica with trimethylchlorosilane. Journal of Non-Crystalline Solids 352: 3762-3771. 
Zhao, X.S.\& Lu, G.Q. 1998. Modification of MCM-41 by surface silylation with trimethylchlorosilane and adsorption study. The Journal of Physical Chemistry B 102: 1556-1561.

\section{T. Areerob}

Division of Environmental Technology

Joint Graduate School of Energy and Environment

King Mongkut's University of Technology Thonburi 10140 Thailand

S. Chiarakorn*

Division of Environmental Technology

School of Energy, Environment and Materials

King Mongkut's University of Technology Thonburi 10140 Thailand
N. Grisdanurak

Department of Chemical Engineering

Thammasat University

12120 Thailand

\section{T. Areerob}

Center for Energy Technology and Environment

Ministry of Education

Thailand

*Corresponding author; email: Siriluk.chi@kmutt.ac.th

Received: 14 January 2014

Accepted: 25 August 2014 